Acta Technologica Agriculturae 1

Nitra, Slovaca Universitas Agriculturae Nitriae, 2017, pp. 7-10

\title{
JERUSALEM ARTICHOKE AS A MEANS OF FIELDS CONSERVATION
}

\author{
Victor STAROVOYTOV ${ }^{1}$, Oksana STAROVOYTOVA ${ }^{1}$, Nikolay ALDOSHIN ${ }^{* 2}$, Alexandra MANOHINA ${ }^{2}$ \\ ${ }^{1}$ All-Russian Research Institute of Potato Farming named after A. G. Lorch, Russia \\ ${ }^{2}$ Russian State Agrarian University - Moscow Timiryazev Agricultural Academy, Russia
}

\begin{abstract}
In Russia, the cultivated fields represent a major issue. According to various estimates, they occupy 20-40 million hectares. Of course, this is a great reserve for the development of agriculture and, if necessary, production of in-demand crops. However, if the fields are not used for a long term, they become gradually overgrown with weeds during quarantine: ragweed, hogweed, shrubs and trees. Subsequent introduction of these fields in turnover requires multiple treatments of the soil and the use of potent herbicides due to the high cost of the uprooting of trees. Based on the decisions of the Russian Federation on land conservation, the land management project defining the terms of land conservation, prevention of land degradation, restoring of soil fertility and bringing of life to contaminated areas as well as the order of how these activities should be carried out and their cost and suggestions for land use after the completion of the mentioned processes was developed. However, the technology of land conservation is yet to be developed.
\end{abstract}

Keywords: Jerusalem artichoke; conservation; green mass; rotations

The Jerusalem artichoke (sunflower tuber) or, as it is called in Russia, 'artichoke' is a perennial tuber plant of the family Asteraceae. The Jerusalem artichoke is a close relative of 'sunflower'. To Russia, the Jerusalem artichoke came in the $18^{\text {th }}$ century from the other end of the world. Homeland of this plant is considered North America (Starovoytov, 2011; Starovoytov, 2002).

The purpose of the article is to show the possibility of using the Jerusalem artichoke as a mean of field conservation.

The objectives of the study are to make recommendations on the use of Jerusalem artichoke as a mean of field conservation and to show the ability to remove the weeds from fields with the Jerusalem artichoke.

The Jerusalem artichoke is a unique plant in many ways. Firstly, we will list its constituent minerals:

- iron (12 mg\%) - magnesium (30 mg\%)

- potassium (200 $\mathrm{mg} \%$ ) - manganese (up to $45 \mathrm{mg} \%$ )

- calcium (40 mg\%) - phosphorus (up to $500 \mathrm{mg} \%$ )

- silicon (up to $8 \mathrm{mg} \%$ ) - zinc (up to $500 \mathrm{mg} \%$ ).

This optimal ratio of minerals enhances the functional activity of the immune, endocrine and nervous systems of the human body and improves the blood state.

Secondly, the Jerusalem artichoke is rich in vitamins. In the tubers of the Jerusalem artichoke, there are quite a lot of $C$ and $B$ vitamins as well as vitamin $E$ and carotenoids. The amount of carotene in the Jerusalem artichoke is $60-70 \mathrm{mg}$ per 1 kilogram (Mimiola, 1988; Kays and Nottingham, 2007).

Thirdly, the Jerusalem artichoke contains large amount of organic polyacids, including citric acid, malic acid, raspberry acid, succinic acid, and fumaric acid. In combination with vitamin C, they possess distinct antioxidant properties.
Fourth, the tubers of Jerusalem artichoke are rich in protein $(3.2 \%$, dry matter). Jerusalem artichoke proteins contain many amino acids (16), including 10 essential (they are not produced by the human body and come from food): arginine, valine, histidine, isoleucine, leucine, lysine, methionine, threonine, tryptophan, phenylalanine.

According to the Novosibirsk Scientific Research Institute of Clinical Immunology SB RAMS, these protein compounds are very close in structure to proteins of the thymus gland (thymus) - they have practically identical properties to those of thymus, major regulators of maturation and functional activity of cells of the immune system.

Fifth, the Jerusalem artichoke is rich in pectin (approximately $11 \%$ of dry matter weight). Pectins are high molecular weight carbohydrates that make up the cell membrane and intercellular substance. Pectins have absorbent, astringent and thickening properties. They reduce the level of cholesterol in the body, improve metabolic processes, normalize bowel movements, and improve the peripheral circulation. But the most valuable feature of pectin is its ability to clear up the organisms without leaving any 'garbage' and not breaking of the balance of the internal body environment.

Sixth, in the tubers of Jerusalem artichoke, there is the highest concentration of rare natural biologically active substances - inulin (up to 17\%). Natural fructose consisting of inulin is a unique sugar that is able to participate in the same metabolic processes like glucose and can fully replace it in situations when glucose is not absorbed by the cells. That is the reason why the inulin has significant health value for diet (Starovoytov, 2011; Starovoytov, 2002; Aldoshin and Didmanidze, 2015; Shahgholi et al., 2015). 
The Jerusalem artichoke can be considered one of the promising crops that can be used for preservation of fields. It can be successfully used as ameliorant in reclamation of soils around industrial areas. It can be grown on lands withdrawn from agricultural turnover because of the extraction of coal, oil, former quarries, ash and industrial waste dumps. The Jerusalem artichoke grows well in places where the forestry and pulp and paper industry wastes are congregated. After 3-5 years of growing this crop on such a land, the soil restores its fertility. Planting the Jerusalem artichoke prevents the wind erosion of the soil, the migration of ash and salt, creating green barriers, it reinforces levees from erosion, and reduces drainage of waste water. The Jerusalem artichoke is able to fully survive on fields with weeds such as couch-grass, sow thistle, cyclorama and others. When this plant is used for remediation of soils, the costs of other necessary technology is significantly reduced and simultaneously, the useless soil is turned into a land fit for agricultural use (Simakov and Starovoytov, 2007; Kays, 1985; Kays and Kultur, 2005; Macák et al., 2015).

Usanova and Pavlov (2016) researched the possibility of using the Jerusalem artichoke as ameliorant in acid rain contaminated sod-podzolic soil. The results of their observation were the following phenomena - positive influence of soil pollution on the growth and development of Jerusalem artichoke plants, yield accumulation of leaf-stem mass, crude protein in the tops and tubers, and absence of harmful effects on the soil.

The Jerusalem artichoke may, in some cases, compete with the hogweed, as this plant is able to reproduce only by seed and is not capable of vegetative reproduction. The Jerusalem artichoke is, on the contrary, reproduced mainly vegetatively. This is due to the facts that the seeds have low germination in general, and a number of varieties of the Jerusalem artichoke bloom only in certain climatic zones (Simakov and Starovoytov, 2007; Milord, 1987).

\section{Material and methods}

From 2008 to 2016, the research on the possibilities of using the Jerusalem artichoke for the preservation of the fields not used in crop rotation was performed in the Moscow region.

It should be noted that in our experience work in the Moscow, Lipetsk regions, as well as in other regions, the artichoke effectively displaces the following weeds: cyanosis; couch grass; bindweed; pigweed white; amaranth; etc.

Eight-years long cultivation experience of the Jerusalem artichoke in the fields of the Moscow region showed that the plant gives a large yield of biomass in the form of green mass and tubers.

Being able to absorb carbon from the air and release oxygen, K. A. Timiryazev considered the Jerusalem artichoke one of the most intensive field crops. And this is the way for creating of effective green belts around industrial centres. One hectare of forest can absorb 3-4 tons of carbon dioxide, whereas one hectare of the Jerusalem artichoke can absorb 6 tons of carbon dioxide (Simakov and Starovoytov, 2007).

Due to the fact that the strong stems of Jerusalem artichokes are a good raw material for the pulp and paper industry, planting a hectare of artichoke can save five hectares of forest.

The Jerusalem artichoke tolerates winter very well and despite the strong winter, there are sprouts next year. If the artichoke is not removed and it is left to continuously grow for next year until the frost period, it would gradually transfer plastic substances from the ground part to the tubers. In the spring, if the Jerusalem artichoke is not removed from the field, there are new shoots on tuber rhizome. Jerusalem artichokes fruit from year to year. In growth, the process of gradual thickening takes place, reducing the yield of tubers and green mass. Tubers become shallower. Depending on climatic conditions, yield decreases evenly. Gradually, it accumulates diseases such as Sclerotium, Septoria blotch rot, etc. However, it should be noted that there is some 'selfcleaning' of the Jerusalem artichoke from diseases in winter according to our observations. As a result of exposure to low temperatures and frost, there is a natural disinfection of the soil and the 'recovery' of new plants. Because of the high competition between plants in subsequent years, the colour of the leaf blade sometimes becomes of lighter green. The leaves are lighter. Gradually, the yield of green mass and tubers is reduced. If cultivated for several periods, yields dramatically increase in the spring because of natural weeding and destruction of plant competitors in cultivation and thus reducing the soil density.

\section{Results and discussion}

Thus, the field disposed of Jerusalem artichoke does not give a field overgrown with weeds and trees. Nine years of experience show that in the process of growth of Jerusalem artichoke, the soil is maintained in good condition and it even recovers due to the annual large biomass in the form of a stem mass, tubers and rhizomes that hit the ground. In addition to this, the Jerusalem artichoke is a great food for hares, rabbits, roe deer and wild boar.

During the 9 years of cultivation, the yield of Jerusalem artichoke reached a certain level, determined by weather conditions; however, the yield started to decrease after the first two years (Table 1).

\section{Fighting diseases, pests and weeds}

Due to the high resistance of the Jerusalem artichoke, treatment with herbicides, insecticides and fungicides was carried out in order to exterminate diseases, pests and

Table 1 The yield of tubers and green mass of perennial plantings of Jerusalem artichoke ( $\mathrm{t}$ ha ${ }^{-1}$ ) per cultivation period without harvest, Korenevo village, Moscow area

\begin{tabular}{|l|c|c|c|c|c|c|c|c|}
\hline Biological yield in $\mathbf{~ t ~ h a ~}^{-1}$ & Year $\mathbf{1}$ & Year $\mathbf{2}$ & Year 3 & Year 4 & Year $\mathbf{5}$ & Year $\mathbf{6}$ & Year $\mathbf{7}$ & Year 8 \\
\hline Tubers, just & $20( \pm 5)$ & $50( \pm 10)$ & $25( \pm 10)$ & $15( \pm 10)$ & $10( \pm 6)$ & $6( \pm 4)$ & $5( \pm 4)$ & $5( \pm 4)$ \\
\hline Green mass & $18( \pm 4)$ & $35( \pm 7)$ & $40( \pm 10)$ & $35( \pm 7)$ & $25( \pm 6)$ & $26( \pm 4)$ & $25( \pm 4)$ & $32( \pm 10)$ \\
\hline
\end{tabular}



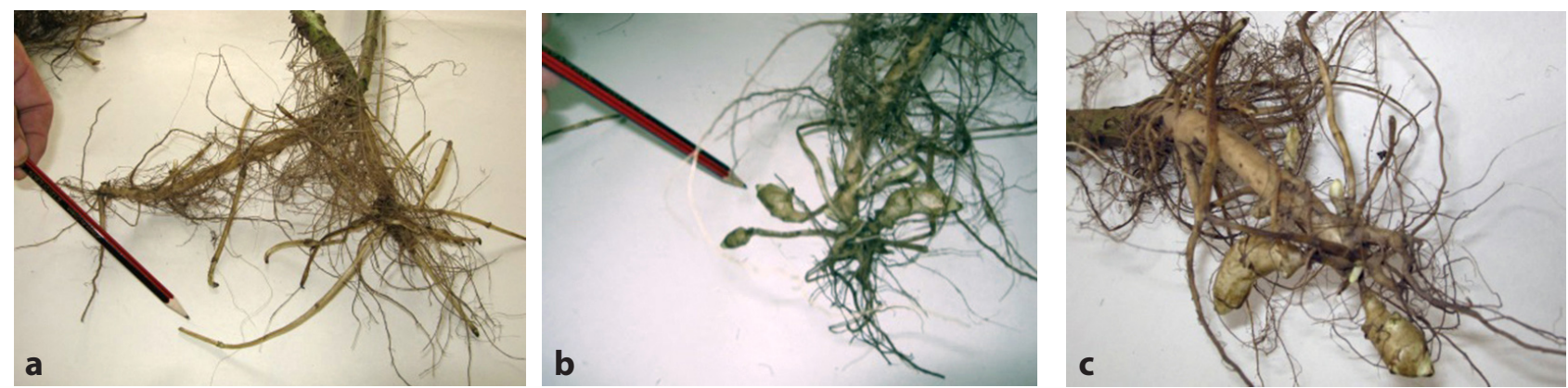

Figure 1

Phases of development of the tubers and rhizomes in which the removal of the plant from the field is most critical

weed vegetation. Herbicides were tested in the experiment. This culture may be affected by pests and diseases during the whole process of growing and breeding. Usually, these problems result from the poor quality seed and improper care. It is not recommended to place the sunflower seeds and carrots near the plantings of Jerusalem artichoke. The most harmful pests for artichokes are considered slugs and mole crickets. Slugs harm the Jerusalem artichoke plantings - they consume the tubers. In order to reduce the impact of pests, the seed tubers were treated with the planting protective drugs.

The question how to subsequently get rid of the Jerusalem artichoke from crop rotation often arises.

There are three general approaches for removing of the Jerusalem artichoke as a weed: the use of chemicals, machinery and crop rotation. The choice of method depends on a number of factors such as the need for continuous cultivation of crops in crop rotation, costs, geographical region, availability of necessary equipment, density of weeds and other factors.

The use of herbicides is important in crop rotation after removing the Jerusalem artichoke crop. When monocot crops follow the Jerusalem artichoke crops in crop rotation, it is possible to apply a wider range of herbicides that can be used for growing and treating the plants because of their selective effects on crops. The effectiveness of herbicides varies. Initially, pre-emergence application of glyphosate usually reduces the pressure of weeds; however, late germination of the Jerusalem artichoke reduces the effectiveness of herbicides. In herbicide treatment, however, when dicotyledonous crop comes after Jerusalem artichoke, it is not recommended to use pre-emergence herbicides such as glyphosate or paraquat, because they tend to give poor results and they depend on the contamination density of the Jerusalem artichoke and its condition before treatment. The deeper the tubers are, the more time is required for their germination. Tubers sprout long after the appearance of cultivated plants, and these herbicides are not applicable then.

Mechanical removal of Jerusalem artichoke usually requires tillage or mowing in two or three repetitions. In areas with mild winters, where the dormant tubers can survive, an additional processing is needed in the next year.

The sowing of green manure crops such as mustard, sweet clover, rape or mixture of wheat for feed can also help to suppress artichoke.

In the initial stage, vetch-oat mixture germinates faster and therefore is in a better position.
The struggle with the Jerusalem artichoke deserves more attention, because this plant is very competitive in crops in almost all agricultural areas. Despite the careful harvesting, sufficient number of small tuber stolons remains in the soil that will contaminate the crop in the next year. In addition to this, a small percentage of tubers may remain dormant in the soil for the next planting season and, depending on location and varieties, they might not germinate until the following year.

The removing of Jerusalem artichoke from the crop rotation takes usually 3 years and it includes the use of mechanical mowing of green mass and ploughing of the young shoots. This is particularly effective at the stage when the mother tubers had already lost their potential and the plants are still in the germination stage.

As a plant, the Jerusalem artichoke is very competitive towards weeds. As a weed, the Jerusalem artichoke represents the greatest challenge because it is a self-seeding plant after harvest.

After harvest, most tubers and rhizomes remain in the upper soil layer from $10 \mathrm{~cm}$ to $15 \mathrm{~cm}$ and are able to generate new shoots in the next season. However, the deeper the shoots are in the soil, the probability of successful development of shoots is lower. For example, shoots in the depth of $25 \mathrm{~cm}$ germinate only in $25 \%$ of cases.

Tubers produce shoots within 50-60 days. It is the underground tubers and rhizomes which make the elimination of the Jerusalem artichoke by mechanical means and by herbicides difficult, as the underground parts can hibernate and produce new plants in the next year (Simakov and Starovoytov, 2007).

The mechanical removal of artichoke crops is particularly effective in a certain growth period of the artichoke. In the central Russia, it is the end of June. Fig. $1(a, b, c)$ present the phases of development of the Jerusalem artichoke in which the most effective mechanical removal is used after continuous milling of land until the autumn when there are only few individual plants of Jerusalem artichoke in the field.

Usanova et al. (2003) suggested the method of breeding Jerusalem artichoke that includes the following: spring cultivation of the soil to a depth of $8-10 \mathrm{~cm}$ after harvest, treatment of vegetating plants with the herbicide Roundup at a dose of 4-6 litres per hectare in a period of massive growth of stolons.

\section{Conclusions}

1. The Jerusalem artichoke can be used for field preservation. It can be used for reclamation of soils around industrial 
areas. After 3-5 years long growth of Jerusalem artichokes, the soil restores its fertility. It prevents wind erosion of the soil, the migration of ash and silt, creates green barriers, reinforces levees from erosion, and reduces drainage of waste water. The Jerusalem artichoke is capable to survive in the fields overgrown with weeds. When this plant is used for remediation of soils, the costs of other necessary technology is significantly reduced and simultaneously, the useless soil is turned into a land fit for agricultural use.

2. As a result of exposure to low temperatures and frosts, there is a natural disinfection of the soil and the 'recovery' of new plants in the winter. The removing of Jerusalem artichoke from the crop rotation takes usually 3 years and it includes the use of mechanical mowing of green mass and ploughing of the young shoots. The mechanical removal of artichoke crops is particularly effective in a certain growth period of the artichoke which is at the end of June in the central Russia.

\section{References}

ALDOSHIN, N. V. - DIDMANIDZE, R. N. 2015. Engineering Quality Assurance Mechanical Works. Monograph, Publishing house of Russian State Agrarian University-MTAA, 2015, 188 pp. ISBN 978-5-9675-1313-8.

KAYS, S. J. 1985. The physiology of yield in the sweet potato. In Sweet Potato Products: A Natural Resource of the Tropics. Bouwkamp, J., Ed., CRC Press, Boca Raton, FL, 1985. pp. 79-132.

KAYS, S. J. - KULTUR, F. 2005. Genetic variation in Jerusalem artichoke (Helianthus tuberosus L.) flowering date and duration. In HortScience, vol. 40, 2005, pp. 165-167.

KAYS, S. J. - NOTTINGHAM, S. F. 2007. Biology and Chemistry of Jerusalem Artichoke: Helianthus tuberosus L. CRC Press, 2007. 496 pp. ISBN 9781420044959.

MACÁK, M. - GALAMBOŠOVÁ, J. - RATAJ, V. - INGELI, M. VITÁZKOVÁ, B. - ĎUĎÁK, J. - ŽITŇÁK, M. 2015. Crop residues distribution after tillage operations under controlled and random traffic technology. In Acta Technologica Agriculturae, vol. 18, 2015, no. 3, pp. 88-91.

MILORD, J. P. 1987. Cycle de developpement de deux varietes de topinambour (Helianthus tuberosus L.) en conditions naturelles. In Evolution physiologique et conservation des tubercules durant la periode hivernale. Limoges, France : These Universite Limoges, 1987.

MIMIOLA, G. 1988. Test of topinambour cultivation in southern Italy. In Topinambour (Jerusalem artichoke), Report EUR 11855, Grassi, G. and Gosse, G., Eds., Commission of the European Communities, Luxembourg, 1988, pp. 53-60.

SHAHGHOLI, H. - MAKARIAN, H. - SHOKATI, B. - TALAEI, G. H. ASGHARIPOUR, M. R. 2015. Do tillage methods affect germination and species similarity of soil weed seeds bank? In Acta Technologica Agriculturae, vol. 18, 2015, no. 4, pp. 97-101.

SIMAKOV, E. A. - STAROVOYTOV, V. I. 2007. Potatoes and Jerusalem artichoke - products of the future. In Informagrotekh, 2007, p. 292. STAROVOYTOV, V. I. 2011. Innovative development of potato and Jerusalem artichoke for 2012-2015//Innovative development of potato and Jerusalem artichoke. VI forum of projects of Union state programs. M., Federal State. Special issue, no. 12(58/1), December, 2011, pp. 56-63.

STAROVOYTOV, V. I. 2002. Jerusalem artichoke - culture of the $21^{\text {st }}$ century. In Machinery and Equipment for Village, 2002, no. 4, p. 5.

STAROVOYTOV, V. I. 2002. Technology and mechanization of cultivation of Jerusalem artichoke. In Materials of the $1^{\text {st }}$ international conference 'Plant Resources for Human Health (Cultivation, Processing, Marketing)', 23-27 Sept. 2002 M, Sergiev Posad. 10.

USANOVA, Z. I. - PAVLOV, M. N. 2016. The possibility of using Jerusalem artichoke as phytomeliorant in acid rain contaminated sod-podzolic soil. In Ecology and Industry of Russia, 2016, no. 10, pp. 37-41.

USANOVA, Z. I. - SKVORTSOV, S. S. - AZERBAEV, A. K. 2003. Method of combating undesirable growth of Jerusalem artichoke. The patent for invention RUS 2265300 29.12.2003. 